\title{
The Impact Of Perceived Value On Spa Loyalty And Its Moderating Effect Of Destination Equity
}

Jirawat Anuwichanont, Ph.D., Suan Dusit Rajabhat University, Thailand Panisa Mechinda, Ph.D., Rajamangala University of Technology, Thailand

\begin{abstract}
Numerous empirical studies have extensively investigated perceived value as a unidimensional measure in the product and service setting. However, research scholars argued that this unidimensional conceptualization lacks validity and assumes that consumers have a shared meaning of value. Moreover, this unidimensional measure fails to give marketing practitioners specific direction on how to improve value. Thus, the multi-dimensional conceptualization of perceived value including five dimensions (quality, emotional response, monetary price, behavioral price and reputation) was employed to investigate service loyalty in the spa industry. This study aims to examine the relative effects of perceived value dimensions on satisfaction and trust and the impact of satisfaction and trust on loyalty. The moderating effects of destination equity are also taken into account. The empirical results support the significant impact of quality, emotional response, monetary price, reputation on satisfaction and trust as hypothesized. In contrast, no support was found on the link between monetary price and trust and between behavioral price and satisfaction and trust. Consistent with previous studies, the impact of satisfaction and trust on loyalty constructs were significantly supported. The moderating effect of destination equity on the relationship between satisfaction and loyalty was significantly apparent. In contrast, no support for the moderating effect of destination equity on the influence of trust on loyalty was found. Implications of the results are discussed.
\end{abstract}

Keywords: Perceived value, Loyalty, Destination equity, Spa industry, Health tourism

\section{INTRODUCTION}

$\mathrm{n}$ the consumer marketing community, customer loyalty has long been regarded as important goal (Reichheld and Schefter, 2000). Both marketing academics and professionals have attempted to uncover the most prominent antecedents of customer loyalty (Yang and Peterson, 2004). Numerous studies have pointed out that two of the more effective means of generating customer loyalty are to delight customers (Lee et al., 2001; Oliver, 1999) and to deliver superior value (Parasuraman and Grewal. 2000). Furthermore, in order to relate to a company, customers must have their trust won. Relationships are maintained based on the ability of company to keep its promise (Perin et al., 2006). However, there are forces that encourage variety seeking and switching behaviors (Beckett et al., 2000). These include: increasing awareness of alternatives (Meidan, 1996) and rising expectations (Ennew et al., 1995) as well as switching incentives (Lewis and Soureli, 2006). This, in turn, retaining customers becomes very difficult (Harrison, 2000). As a result, companies need to consider the antecedents of customer loyalty and their relative importance, in order that they may try to impact on them in the provision of services (Lewis and Soureli, 2006).

\section{RESEARCH OBJECTIVES}

The objectives of this research are threefold; first to examine the relative effects of perceived value dimensions and the nature of its effects on satisfaction and trust, second to examine the impact of satisfaction and 
trust on loyalty and third to investigate the moderating effects of destination equity on the link between satisfaction, trust and loyalty.

\section{LITERATURE REVIEW AND CONCEPTUAL DEVELOPMENT}

\section{Perceived Value}

The construct of perceived value has been identified as one of the most important ingredients for gaining competitive edge (Parasuraman, 1997) and the most important indicator of repurchase intentions (Parasuraman and Grewal, 2000). Zeithaml (1988, pp. 14) has defined perceived value as 'the consumer's overall assessment of the utility of a product based on perceptions of what is received and what is given. Briefly defined, perceived value is the result or benefits customers receive in relation to total costs (Woodruff, 1997). Perceived value is most commonly used as a unidimensional measure (Gale, 1994). However, research scholars argued that this unidimensional measure lacks validity (Woodruff and Gardial. 1996) and it assumes that consumers have a shared meaning of value (Petrick, 2004).

Past research has developed multi-dimensional scale of perceived value in a product setting (Sweeney and Soutar, 2001) as well as in a service setting (Petrick, 2002). According to Sweeney and Soutar (2001), perceived value of product constitutes four dimensions: emotional, social, quality/performance and price/value for money. In addition, Petrick (2002) found that perceived value of service comprises five dimensions: quality, emotional response, monetary price, behavioral price and reputation. Quality was defined as consumers' judgments about a service's overall excellence (Zeithaml, 1988). Emotional response was defined as the descriptive judgment regarding the pleasure that a service gives the purchaser (Sweeney et al., 1998). Monetary price was defined as the price of a service as encoded by the consumer (Jacoby and Olson, 1977). Behavioral price was defined as the nonmonetary price of obtaining the service that included time and effort used to search for service (Zeithaml, 1988). Finally, reputation was defined as the status of a service as perceived by the consumer, based on the image of the supplier (Dodds et al., 1991). In this study, we believe that marketers could benefit from multidimensional measure of perceived value by allowing them to compare the relative importance of each dimension and identifying the dimensions that being perform well or poor in an attempt to give specific direction on how to improve value (Petrick, 2004). Consistently, Woodruff (1997) stated that the managers need in-depth understanding about what customer values to guide them how to respond efficiently.

\section{Satisfaction}

Past research has suggested that satisfaction is an excellent predictor of repurchase intentions (Petrick, 2002). Rust and Oliver (1994) stated that satisfaction reflects the degree to one believes that an experience evokes positive feelings. Thus, satisfaction is an overall affective response due to the use of product or service (Oliver, 1981). An assessment of satisfaction has been attempted using various perspectives and theories, e.g., expectation/disconfirmation model, equity, norm and perceived overall performance. According to Oliver (1980), there are four essential constructs in the expectation-disconfirmation model (Oliver, 1980): expectation, performance, disconfirmation and satisfaction. Customers can develop their expectations of a product/service performance from various sources of communication. After consumption, three possibilities can occur: zero disconfirmation can result when product performs as expected; positive disconfirmation can occur when product perform better than expected and negative disconfirmation can occur when the product perform below expectation. However, the use of expectations to measure satisfaction has been argued (Petrick and Backman, 2002). According to Barsky (1992), expectations have been frequently accepted as affecting satisfaction, yet there is inconclusive evidence that they directly lead to satisfaction or dissatisfaction. One problem with the model is that if one's expectations are decreased, their satisfaction must inevitably increase. Thus the model would suggest that consumers who expect and receive poor performance will be satisfied (LaTour and Peat, 1979). Furthermore, based on the intangible nature of service, expectation on service are relatively weak. This makes information on expectations less concrete and less useful (Johnson, 1998). Thus, while expectations may assist in the understanding of satisfaction formation, they have been found to be detrimental in trying to predict future purchase intentions (Petrick and Backman, 2002). In this study, we have employed perceived performance model developed by Tse and Wilton (1988). According to this model, consumer dissatisfaction is only a function of the actual performance regardless of 
consumers' expectations. This model is effective when customers do not know or not have enough knowledge about service performance, and only their actual experiences are evaluated to assess their satisfaction (Petrick, 2004).

\section{Trust}

Relationship marketing literature has documented trust as an important determinant of commitment (Ganesan, 1994). It is essential for brands to be perceived as being reliable and dependable, and the firm to be honest, trustworthy (Wang, 2002) since mistrust will decrease customer commitment and the likelihood of purchase. Trust is seen as an expression of security between partners when making an exchange (Garbarino and Johnson, 1999) or as a willingness to rely on an exchange partner in whom one has confidence (Moorman et al., 1993). In this study, trust is defined as the expectation held by the consumer that the service provider is dependable and can be relied on to deliver on its promises (Sirdeshmukh et al., 2002, p.17). Previous studies have suggested that trust is composed of three variables: company's competence, benevolence and orientation toward problem solving (Barclay and Smith, 1997).

The first variable, competence was defined as the degree to which partners perceive each other as having skills, abilities and knowledge necessary for effective performance (Barclay and Smith, 1997). The competence trust was found to be significant predictor of any repeated transaction (Sake, 1992) and buyer's trust in the retail and airline setting (Doney and Cannon, 1997; Sirdeshmukh and colleagues, 2002). Second, the perception of the benevolence is defined as behaviors that reflect an underlining motivation to place the consumer's interest ahead of self-interest (Ganesan and Hess, 1997). Benevolent behaviors are displayed in terms of proconsumer motivation, restraint on self-serving opportunism and a willingness to assume fiduciary responsibility (Morgan and Hunt, 1994). As a result, benevolent behaviors are often regarded as extra-role behaviors that are performed at a cost to the service provider with or without commensurate the benefits. Empirical evidence usually supports the effect of benevolence on trust (Hess, 1995; Smith and Barclay, 1997). Third, the consumer's evaluation of the company's orientation toward problem solving was defined as the degree to which they anticipate and satisfactorily resolve problems that may arise during and after the service exchange (Sirdeshmukh et al., 2002). It is recognized that problems often arise during service delivery due to heterogeneity nature of the service (Bitner et al., 1990). Furthermore, the way the service provider handles the problem in terms of nature and promptness of company effort can be good opportunity to prove commitment to service, which in turn create customer satisfaction and trust (Hart et al., 1990). Previous researches have found that two dimensions of trust: credibility and benevolence are highly correlated and operationally inseparable in practice (Kumar et al., 1995). Furthermore, the trust scale exhibited unidimensionality as a single factor emerged from the factor analysis (Doney and Cannon, 1997). Thus, trust was treated as unidimensional construct in this study.

\section{Loyalty}

Customer loyalty is critical for business to gain competitive advantage. First, it is much less expensive to retain current visitors than it is to seek new ones (Reicheld and Sasser, 1990). Further, loyal customers are more likely to discuss past service experiences positively than non-loyal customers, creating a potential for word-ofmouth advertising at no extra cost to the service provider (Shoemaker and Lewis, 1999). Third, it secures the relationship between customer and service provider, when the customer is faced with increasingly attractive competitive offers, or the supplier's own shortcomings. Finally, loyal customers are more easily accessible than first-timers since organizations usually retain records, making targeted indirect marketing more feasible. This knowledge permits suppliers to precisely target the repeat segment and solicit direct responses to promotions (Reid and Reid, 1993).

Oliver (1999, p. 34) has defined loyalty as 'a deeply-held predisposition to repatronize a preferred brand or service consistently in the future, thereby causing repetitive same brand purchasing, despite situational influences and marketing efforts having the potential to cause switching behavior.' When a customer is loyal, he or she continues to buy the same brand, tends to buy more and is willing to recommend the brand to others (Hepworth and Mateus, 1994). 
Loyalty has been measured in the following ways: (1) the behavioral approach, (2) the attitudinal approach, and (3) the composite approach (Jacoby and Chestnut, 1978). The behavioral perspective defines loyalty as actual consumption, as a sequence of purchase (Brown, 1952), as proportion of market share (Cunningham, 1956), as probability of purchase (Frank, 1962), as duration, as frequency and as intensity (Se-Hyuk, 19962). This behavioral approach was viewed as producing only static outcome of a dynamic process (Dick and Basu, 1994). In contrast, the attitudinal approach goes beyond overt behavior and expresses loyalty in terms of consumers' strength of affection toward a brand (Backman and Crompton, 1991). Finally, composite measures of loyalty integrate both behavioral and attitudinal dimensions. Day (1969) argues that to be truly loyal, a consumer must both purchase the brand as well as have a positive attitude toward it. This composite approach seems to be the most comprehensive, it is not necessarily the most practical. It has serious inherent limitations, simply because of the weighting applied to both behavioral and attitudinal components.

The measurement of loyalty in a tourism context is particularly difficult, since the purchase of a tourism product is a rare purchase (Oppermann, 1999). It does not occur on a continuous basis but rather infrequently (Jago and Shaw, 1998). It can also be covert behavior as reflected in intention to revisit in the future (Jones and Sasser, 1995). Bei and Chiao (2001) remind us that loyalty is hard to measure, since the process of repetitive purchase might be due to convenience, habits or no alternatives. Hennig-Thurau and colleagues (2002) state that loyalty is more than a repetitive purchase but it is also related to appreciation and commitment. Loyal customer is publicizing the company and its products through positive word of mouth and through a desire to maintain that relationship (Hennig-Thurau et al., 2002), which is the focus of the current study. This loyalty refers to committed behavior that is manifested by propensity to participate in a particular recreation service and recommendation to others (Oppermann, 2000; Backman and Crompton, 1991). This definition is supported by Jones and Sasser (1995) who argued that intent to repurchase is a very strong indicator of future behavior.

\section{Destination equity}

Brand equity is regarded as a critical concept because marketers can gain competitive advantage through successful brands (Lassar et al., 1995). Brands with high equity enjoy the opportunity for successful extensions, resilience against competitors' promotional pressures and creation of barriers to competitive entry (Farquhar, 1989). A strong brand can differentiate a product from its competitors (Lim and O'Cass, 2001), reduce search costs (Assael, 1995) and minimize perceived risks (Berthon et al., 1999). Brand equity has been examined from two different perspectives- financial and customer based. The first refers to the financial asset value it creates to business franchise (Simon and Sullivan, 1992). The second perspective is customer-based (Keller, 1993). It is defined as the differential effect of brand knowledge on consumer response to the marketing of brand. Financial valuation have little relevance if managers do not know how that value is created from customer's perspective and how to exploit that value by developing profitable brand strategies (Keller, 1993).

This study focuses on customer-based brand equity proposed by Keller (1993). Customer-based brand equity is defined as the differential effect of brand knowledge on consumer response to the marketing of the brand. That is, it involves consumers' reactions to an element of marketing mix for the brand (Keller, 1993, p. 8). Regarding sources of brand equity, different dimensions appear in different frameworks. Aaker $(1991,1996)$ and Keller (1993) are the most frequently referred in this research area (Anselmsson et al., 2007). Aaker (1991, 1996) separates brand equity in four dimensions: loyalty, awareness, perceived quality and associations. Keller (1993) discusses brand equity in terms of awareness and image. This study focuses on Keller's dimension which will be explained in more detail below. The application of branding theories is well documented in the generic marketing literature, however, the application of branding theories to service and tourism context is relatively new (Hosany et al., 2006). In tourism, there is one study which measure brand equity of Slovenia as tourism destination (Konecnik, 2006).

According to Keller (1993), brand equity or brand knowledge comprises two dimensions: brand awareness and brand image. Brand awareness is related to the strength of the brand node in memory, as reflected by customer's ability to identify the brand under different conditions (Rossiter and Percy, 1987). It reflects the presence of a brand in the minds of customers (Konecnik, 2006) Brand awareness consists of brand recall and brand recognition (Keller, 1993). Brand image is defined by Keller (1993) as perceptions about the brand as reflected by the brand association 
held in consumer memory. In tourism research, destination image is defined as an attitudinal concept of the sum of beliefs, ideas and impressions that a tourist hold of a destination (Crompton, 1979). An increasing number of research supports the view that destination image consists of two dimensions: cognitive and affective (Hosany et al., 2006). The cognitive component can be interpreted as beliefs and knowledge about physical attributes of a destination, while the affective component refers to the feelings towards the attributes and environments (Baloglu and McCleary, 1999). In this study we apply the concept of branding into the service/tourism context by investigating the effects of brand or destination equity on the link between satisfaction and loyalty as well as the link between trust and loyalty.

\section{HYPOTHESES DEVELOPMENT}

\section{Hypothesized relationship between perceived value and satisfaction}

Empirical research have shown that perceived value is a key determinant of repurchase intention (Cronin $e t$ al., 2000; Petrick 2004). However, others have provided evidence that the effect of perceived value on repurchase intention was completely mediated via customer satisfaction (Patterson and Spreng, 1997). Based on equity theory (Oliver and DeSarbo, 1988), customers are inclined to feel equitably treated if they perceive that the ratio of their outcome to inputs is comparable to the ratio of outcome of inputs experience by the company. As a consequence, they are more likely to be satisfied with the service (Bolton and Drew, 1991). In light of the preceding discussion and findings we propose that:

H1a: Perceived value (quality dimension) will positively influence customer satisfaction.

H2a: Perceived value (emotional response dimension) will positively influence customer satisfaction.

H3a: Perceived value (monetary price dimension) will positively influence customer satisfaction.

H4a: Perceived value (behavioral price dimension) will positively influence customer satisfaction.

H5a: Perceived value (reputation dimension) will positively influence customer satisfaction.

\section{Hypothesized relationship between perceived value and trust}

Morgan and Hunt (1994) have pointed out that trust being a key element in developing strong and longterm relationship with customers. Furthermore, they have indicated that the benefits of the relationship are precursors of trust. The perceived value of a service can be considered part of the benefits of the relationship (Sanchez-Garcia, 2007; Singh and Sirdeshmukh, 2000). When customers perceive the benefits (monetary, functional, emotional, prestige, and effort) received higher than the costs of obtaining such benefits, customers are more inclined to put more trust in the service provider and maintain relationship. Although some scholars have posited causality in a different direction (Sirdeshmukh et al., 2002) that trust is an antecedent to perceived value.

H1b: Perceived value (quality dimension) will positively influence trust.

H2b: Perceived value (emotional response dimension) will positively influence trust.

H3b: Perceived value (monetary price dimension) will positively influence trust.

H4b: Perceived value (behavioral price dimension) will positively influence trust.

H5b: Perceived value (reputation dimension) will positively influence trust.

\section{Hypothesized relationship between satisfaction and loyalty}

It is well established in the packaged good markets and service markets that the major determinant of customer loyalty is satisfaction (Oliver, 1999). In particular, research evidence also supports that satisfaction is a precursor of trust, retention and repeat purchase intention (Olsen, 2002). However, the relationship between satisfaction and behavioral intention is non-linear, indicating that when satisfaction rises above a certain threshold, loyalty climbed rapidly vice versa (Oliva et al., 1992). If they are satisfied, they will be more likely to continue to purchase. Similarly, if they are dissatisfied, they will be more likely to switch to another alternative (Oliver and Swan, 1989). However, it is important to note that the degree of satisfaction's impact on loyalty is not the same for all industries or all situations (Kozak and Rimmington, 2000; Fornell, 1992). Based on the above discussion, the hypotheses are developed as follows: 
H6: Customer satisfaction will positively influence loyalty.

\section{Hypothesized Relationship between trust and loyalty}

The literature has shown that trust is a precursor of commitment (Sanchez-Garcia et al., 2007). Kramer (1999) considers that trust reduces the transaction costs of searching information on prices and alternatives available in the market. The higher the level of trust is hold by customers, the lower the transaction costs, and the greater commitment to service provider. Additionally, trust is a feeling of security, based primarily on the belief that one party's behavior is guided by favourable intention towards the best interests of the other, and secondly on the competence of a business to keep promises (Delgado-Ballester and Munuera-Aleman, 2001; Lewis and Soureli, 2006). Because of emotional nature of loyalty, trust in service provider's reliability and integrity is very important (Bejou et al., 1998) As a result, we hypothesize that

H7: Customer trust will positively influence loyalty.

The moderating effects of destination equity (destination awareness and image)

According to literature review, we have found that awareness of product is essential, first stage model in consumer behavior. Ehrenberg and Goodhart (1989) presented that there are three stages of purchasing and consuming: awareness, trial and repeat buying (ATR). Russ and Kirkpatrick (1982) suggested five stages: awareness, interest, desire, action and reaction. All of these models suggested that for repeat buying to occur, there must first be a trial purchase and consumption. Furthermore, for trial purchase to occur, there must first be awareness (Milman and Pizam, 1995). Though, product awareness is a first and necessary step to repeat purchase, it is not a sufficient one. Awareness may not always lead to purchasing behavior. Fesenmaier et al. (1993) found that information collected by travelers at welcome center information did not actually influence travel behavior. Awareness results in curiosity that leads to trial. Therefore for a tourism destination to be successful it must first have awareness and positive image (Milman and Pizam, 1995). Furthermore, several studies have illustrated that destination images influence tourist behavior (Hunt, 1975, Pearce, 1982). That is, destinations with strong positive images are more likely to be considered in the travel decision process (Woodside and Lysonski, 1989). Many studies found that positive images of destination influence destination loyalty (Hernandez-Lobato et al., 2006), and intention to revisit (Gibson et al., 2008; Kaplannidou and Vogt, 2007). Additionally, literature in product branding also indicates that image of a country can influence product preference (Knight and Calantone, 2000; Parameswaran and Pisharodi, 2002; Laroche et al., 2005). That means that people's beliefs and affects about a specific country affect their behavior in relation with the products originating in that country (Parameswaran and Pisharodi, 2002; Montesinos, 2006). As Keller proposed that brand equity (in this regard, destination equity) should result in (1) biased processing of information, (2) persistent attitudes or beliefs that are, (3) resistance to change and (4) behaviours that are influenced by those beliefs. Spa tourists or customers who posses high level of destination equity; that is having aware of destination (Pattaya, Thailand) and having positive images of Pattaya, are more likely to process information about spa services favorably and to display relatively higher loyalty toward spa services industry in Pattaya. Consistent with Raggio and Leone (2007), they indicate that brand equity acts as a moderating effect between marketing activities and brand value. As a consequence, we hypothesize that

H8: The higher the level of destination equity as perceived by customers, the greater is the likelihood that customer satisfaction will lead to greater customer loyalty

H9: The higher the level of destination equity as perceived by customers, the greater is the likelihood that customer trust will lead to greater customer loyalty.

\section{RESEARCH METHODOLOGY}

This study selected health tourism, spa industry in Pattaya, Thailand. Pattaya was ranked as one of the top five major destinations in terms of tourist revenue (www.tat.or.th). Target populations are international tourists who have used spa service (e.g. spa treatment, Thai traditional massage, foot massage) in Pattaya. Derived from indefinite population formula for determining sample size, the calculated sample size for this study is 385 . The researcher team recruited for additional 100 sample as a buffer against invalid questionnaire. Consequently, total 
sample size for this study is 485 . The quota sampling method is employed by allocating 16-17 sample from each of 30 spa services in Pattaya. Total duration of data collection was one month. The first draft of the questionnaire was subjected to pretesting with total respondents of 40 .

\section{Measures}

Perceived value was measured by using 25 -item scale of five dimensions with composite reliability scores greater than 0.70 (Petrick, 2002). Satisfaction was assessed using a three-item scale based on Oliver and Swan (1989) and Patterson et al. (1997) with seven-point Likert rating scale. Trust was measured using a six-item scale adapted from previous studies by Crosby et al. (1990) and Doney and Cannon (1997). The scale reliability in these studies was quite high with alpha coefficients at 0.89-0.94. Regarding loyalty, this study focuses on attitudinal loyalty which was operationalized using the five-item scale developed by Muncy (1983). This four-item scale asked questions about brand preference, consumer willingness to repatronage as well as recommendation the service provider to others. The loyalty scale demonstrated substantial internal consistency with reliability estimates of 0.91 in the previous study of Pritchard et al. (1999). To measure destination equity which comprises two dimensions (awareness and image), we applied the four-item 7-point Likert scale from Konecnik (2006) and from Yoo et al. (2000) to measure awareness of destination. With regards to destination image, researchers suggested two ways of measuring image which are: (1) attribute-based component and (2) holistic component.

\section{Results}

Total number of questionnaires distributed was 485 , but only 479 questionnaires obtained were valid. It can be indicated that there is almost equal split in the gender of respondent ( $49 \%$ are male; $51 \%$ are female). $46 \%$ of them are 25-44 years old. Half of them are married. The majority of them achieves bachelor degree and come from administrative/ managerial level. Most of them have monthly household income level between 1,626-2,000 US\$. The majority of them come from Europe (30\%), East Asia (20\%) and the Americas (20\%).

The preliminary analysis revealed that the measurement scales of quality, emotional response, monetary price, behavioral price, reputation, satisfaction, trust, loyalty, destination awareness and destination image had acceptable internal consistency, which was evidenced by Cronbach's alpha of $0.90,0.92,0.91,0.91,0.91,0.91$, $0.92,0.88,0.81$ and 0.84 respectively which exceeded the threshold value of 0.70 (Nunnally 1978). Exploratory factor analysis (EFA) was conducted using principal component analysis on measurement scales of each construct and only one factor was extracted as expected, which explained approximately $81,80,78,85,85,85,80,85,85$ and 84 percent of the total variance respectively. The findings indicated that all constructs satisfied the criteria of unidimensionality and reliability and therefore could be used for further study.

Following EFA, confirmatory factor analysis using AMOS version 4.01 was undertaken for scale purification and assessing the psychometric properties of measures in terms of testing convergent validity and reliability properties of the measures. To improve both model fit, the items with unacceptably low squared multiple correlation were removed. Through the iteration process, three items were remained for most constructs except destination image. Due to the lack of degrees of freedom, an overall fit criteria could not be obtained from three items in a single-factor model.

The findings of the confirmatory factor analysis revealed that factor loadings of all constructs were all significantly high ranging from 0.74 to 0.97 which exceed the critical value of 0.5 for adequate individual item reliability, providing support for convergent validity (Bagozzi and Yi, 1988). Moreover, t-values of the factor loadings were all statistically significant (t-value > 1.65) ranging from 15.77 to 32.92 , providing some support for convergent validity of the constructs (Anderson and Gerbing, 1988; Bollen, 1989). These findings indicated that all indicators were related significantly to the construct with low standardized residuals which satisfied the requirement of internal consistency and adequate fit of scale items as shown in Table 1.

Additionally, the assessment of internal consistency of the measurement scale was conducted through the examination of composite reliability and variance extracted measures for each construct. Composite reliability represents the shared variance among a set of observed variables that measure an underlying construct while 
variance extracted measures reflects the overall amount of variance in the indicators accounted for by the latent construct (Fornell and Larcker, 1981). The findings showed that all composite reliability of constructs exceeded the threshold level of 0.7 ranging from 0.85 to 0.93 , indicating high internal consistency of the measurement scales (Fornell and Larcker, 1981; Bagozzi and Yi, 1988; Hair et al., 1998). Finally, average variance extracted score for all constructs were close to and exceeded the recommended level of 0.5 ranging from 0.53 to 0.82 , indicating that a higher amount of variance in the indicators was captured by the construct compared to that accounted for by measurement error (Fornell and Larcker, 1981; Hair et al., 1998). The composite reliability and average variance extracted of each construct are summarized in Table1.

Table1: Summary of Measurement Model Results

\begin{tabular}{lcccc}
\hline \multicolumn{1}{c}{ Construct } & No. of items & Factor loading & $\begin{array}{c}\text { Composite reliability } \\
\text { coefficient }\end{array}$ & $\begin{array}{c}\text { Average variance } \\
\text { extracted }\end{array}$ \\
\hline Quality & 3 & $0.85-0.90$ & 0.93 & 0.81 \\
\hline Emotional response & 3 & $0.82-0.93$ & 0.92 & 0.79 \\
\hline Monetary price & 3 & $0.78-0.92$ & 0.90 & 0.75 \\
\hline Behavioral price & 3 & $0.82-0.99$ & 0.91 & 0.78 \\
\hline Reputation & 3 & $0.78-0.99$ & 0.91 & 0.78 \\
\hline Satisfaction & 3 & $0.83-0.91$ & 0.85 & 0.53 \\
\hline Trust & 3 & $0.81-0.97$ & 0.93 & 0.82 \\
\hline Loyalty & 3 & $0.80-0.97$ & 0.91 & 0.78 \\
\hline Destination awareness & 3 & $0.82-0.95$ & 0.91 & 0.77 \\
\hline Destination image & 4 & $0.74-0.83$ & 0.86 & 0.61 \\
\hline
\end{tabular}

\section{Multicollinearity Issues}

Before estimating the hypothesized conceptual model, multicollinearity testing among independent variables is highly recommended to identify the correlation problem among independent variables (Hair et al., 1998; Tabachnick and Fidell, 2001). The correlation values between constructs exceeding 0.90 can be indicative of multicollinearity (Hair et al., 1995). The assessment of multicollinearity can be conducted through examining the tolerance value, variance inflation factor (VIF) and condition index (Hair et al., 1998). The tolerance value is the amount of variability of the selected independent variable not explained by the other independent variables while VIF is tolerance's inverse. The cut-off points for tolerance value and VIF are 0.10 and 10 respectively. The VIF value, the inverse of $\left(1-\mathrm{R}^{2}\right)$, should be close to 1.00 , which indicates little or no multicolinearity and a cutoff value of 10.00 is considered as an acceptable VIF. Thus, a small for tolerance and a large VIF are indicative of multicolinearity. Lastly, multicolinearity can be identified by condition index which is a measure of the dependency of one variable on the others and represents the collinearity of combinations of variables in the data set. Hair et al. (1998) suggested that a condition index threshold of 30 for a given dimension, coupled with at least two variance proportions for an individual variable greater than 0.50 , is the criterion for multicollinearity. According to the correlation matrix (Table 2), all correlations between the independent variables were well below 0.90 , indicating low multicolinearity problem. Both tolerance values (0.39-0.70) and VIF (1.43-2.53) from the multiple regression analysis were in the acceptable threshold. In addition, only one variance proportion for an individual variable was more than 0.50 at the condition index at 27.06 for all measures were lower than 30 in the analysis. The results show that multicollinearity is negligible in this study.

To verify discriminant validity between constructs, AVE should be greater than the squared correlation between a construct and other constructs in the model. Therefore, the square root of the AVE was presented at the diagonal of the correlation matrix shown in Table 2 for the purpose of comparing with the correlation coefficient between constructs (Green et al., 1995). Adequate discriminant validity was evident, because the diagonal elements are greater than the off-diagonal elements in the corresponding rows and columns. 
Table 2: Intercorrelations Among Refined Measures and Average Variance Extracted

\begin{tabular}{|c|c|c|c|c|c|c|c|c|c|c|}
\hline & Y1 & Y2 & Y3 & X1 & $\mathbf{X 2}$ & $\mathbf{X 3}$ & $\mathbf{X 4}$ & $\mathbf{X 5}$ & X6 & $\mathbf{X 7}$ \\
\hline Loyalty (Y1) & .78 & & & & & & & & & \\
\hline Satisfaction (Y2) & $.48 * *$ & .53 & & & & & & & & \\
\hline Trust (Y3) & $.37 * *$ & $.51 * *$ & .82 & & & & & & & \\
\hline Quality (X1) & $.29 * *$ & $.38 * *$ & $.58 * *$ & .81 & & & & & & \\
\hline Emotional Response (X2) & $.23 * *$ & $.34 * *$ & $.36 * *$ & $.46^{* *}$ & .79 & & & & & \\
\hline Monetary Price (X3) & $.23 * *$ & $.18 * *$ & .05 & $.14 * *$ & $.27 * *$ & .75 & & & & \\
\hline Behavioral Price (X4) & $.31 * *$ & $.15 * *$ & .08 & $.14 * *$ & $.22 * *$ & $.70 * *$ & .78 & & & \\
\hline Reputation (X5) & $.36 * *$ & $.30 * *$ & $.30 * *$ & $.36 * *$ & $.33 * *$ & $.27 * *$ & $.51 * *$ & .78 & & \\
\hline Destination Awareness (X6) & $.22 * *$ & $.16^{* *}$ & $.26 * *$ & $.23 * *$ & .06 & .09 & $.10^{* *}$ & .07 & .77 & \\
\hline Destination Image (X7) & $.21 * *$ & $.13 * *$ & .01 & $-.14 * *$ & $-.12 * *$ & $.14 * *$ & $.17 * *$ & -.05 & $.16^{* *}$ & .61 \\
\hline
\end{tabular}

Note: $* *$ Correlation is significant at the 0.01 level (1-tailed), $* *$ Significant at $\mathrm{p}<.001$

*Correlation is significant at the 0.05 level (1-tailed), *Significant at $\mathrm{p}<.05$

Diagonal is square root of average variance extracted

\section{Recursive Path Analysis: Empirical Testing of Hypothesized Model}

After having satisfied the requirements arising from the measurement issues of confirmatory factor analysis, a test of structural relationships using AMOS version 4.01 was conducted to assess the data-model fit and the hypothesized relationships between theoretical constructs. The structural model achieved an overall good fit. The chi-square/degrees of freedom ratio was within the recommended level of 2.00 to $3.00\left(\chi^{2} / \mathrm{df}=2.82\right)$, indicating an acceptable fit, and all goodness-of-fit indices were in the desirable ranges. Though the chi square goodness of fit was significant $\left(\chi^{2}=628.89, \mathrm{df}=223, \mathrm{p}<0.000\right)$, all measures of fit for the structural model indicate sound fit statistics: goodness-of-fit index $(\mathrm{GFI})=0.904$, adjusted goodness-of-fit index $(\mathrm{AGFI})=0.871$, root mean square residual $(\mathrm{RMR})=0.095$, Tucker-Lewis index $(\mathrm{TLI})=0.953$, comparative fit index $(\mathrm{CFI})=0.962$, normed fit index $(\mathrm{NFI})=0.942$, and root mean square error of approximation $($ RMSEA $)=0.061)$. The structural model output displayed in Table 3 shows that the model explained a substantial portion of the variance in all the endogenous variables; satisfaction $22 \%$, trust $39 \%$ and loyalty $24 \%$.

The hypothesis testing was accomplished by examining the completely standardized parameter estimates and their associated $\mathrm{t}$-values. One-tailed tests of significance were used to determine the significance of each path coefficient. In general, estimates were consistent with expectation because all hypothesized relationships were significant $(p<0.001$ and $p<0.01)$ and in the expected direction, with the exception of the relationship between monetary price and trust and between behavioral price and satisfaction and trust. The results demonstrated that quality, emotional response, monetary price and reputation had significant, positive impacts on satisfaction and trust as hypothesized. In addition, the hypothesized relationship between satisfaction and trust and loyalty constructs were significantly supported. In sum, quality was found to be the most powerful predictor of satisfaction $(\beta=0.269)$ and trust $(\beta=0.531)$ while satisfaction was found to be the most powerful predictor of loyalty $(\beta=0.409)$ followed by trust $(\beta=0.138)$. The final structural equation model, shown in Table 3 , indicated support for five hypothesized paths in the theoretical model at the significant level of $0.001(\mathrm{t}>3.09)$ and four hypothesized paths at the significant level of $0.01(\mathrm{t}>2.33)$. The standardized path coefficients along with its associated $t$-values were displayed in Table 3. 
Table 3: Summary of Hypotheses Testing Results Without Moderator Effects

\begin{tabular}{|c|c|c|c|c|c|}
\hline H: & From & To & Standardized estimate & t-values & Supported \\
\hline H1a & Quality & Satisfaction & 0.269 & 5.181 & Yes**** \\
\hline $\mathrm{H} 1 \mathrm{~b}$ & Quality & Trust & 0.531 & 10.467 & Yes $* * * *$ \\
\hline $\mathrm{H} 2 \mathrm{a}$ & Emotion response & Satisfaction & 0.165 & 3.214 & Yes $* * * *$ \\
\hline $\mathrm{H} 2 \mathrm{~b}$ & Emotion response & Trust & 0.106 & 2.376 & Yes*** \\
\hline $\mathrm{H} 3 \mathrm{a}$ & Monetary price & Satisfaction & 0.132 & 2.340 & Yes*** \\
\hline $\mathrm{H} 3 \mathrm{~b}$ & Monetary price & Trust & -0.077 & -1.566 & No \\
\hline $\mathrm{H} 4 \mathrm{a}$ & Behavioral price & Satisfaction & -0.085 & -1.433 & No \\
\hline $\mathrm{H} 4 \mathrm{~b}$ & Behavioral price & Trust & -0.022 & -0.417 & No \\
\hline H5a & Reputation & Satisfaction & 0.168 & 3.300 & Yes**** \\
\hline $\mathrm{H} 5 \mathrm{~b}$ & Reputation & Trust & 0.112 & 2.534 & Yes*** \\
\hline $\mathrm{H} 6$ & Satisfaction & Loyalty & 0.409 & 7.473 & Yes $* * * *$ \\
\hline $\mathrm{H} 7$ & Trust & Loyalty & 0.138 & 2.715 & Yes*** \\
\hline
\end{tabular}

Squared multiple correlations for Satisfaction: 0.229 , Trust: 0.388 and Loyalty: 0.245

Model Goodness-of-fit statistics: Chi-square $=628.89$, Degrees of freedom $=223, \chi^{2} / \mathrm{df}=2.82, \mathrm{p}$ value $=0.000$, GFI $=$ 0.904, AGFI $=0.871, \mathrm{RMSR}=0.095, \mathrm{TLI}=0.953, \mathrm{CFI}=0.962, \mathrm{NFI}=0.942$ and $\mathrm{RMSEA}=0.061$

Note: $* \mathrm{p}=0.10, * * \mathrm{p}=0.05, * * * \mathrm{p}=0.01, * * * * \mathrm{p}=0.001$

Based on one-tailed t-tests: $\mathrm{t}$-values $>1.28, \mathrm{p}<0.10$ : $\mathrm{t}$-value $>1.65, \mathrm{p}<0.05$ : and $\mathrm{t}$-value $>2.33, \mathrm{p}<0.01$, and $\mathrm{t}$-values $>$ $3.09, \mathrm{p}<0.001$

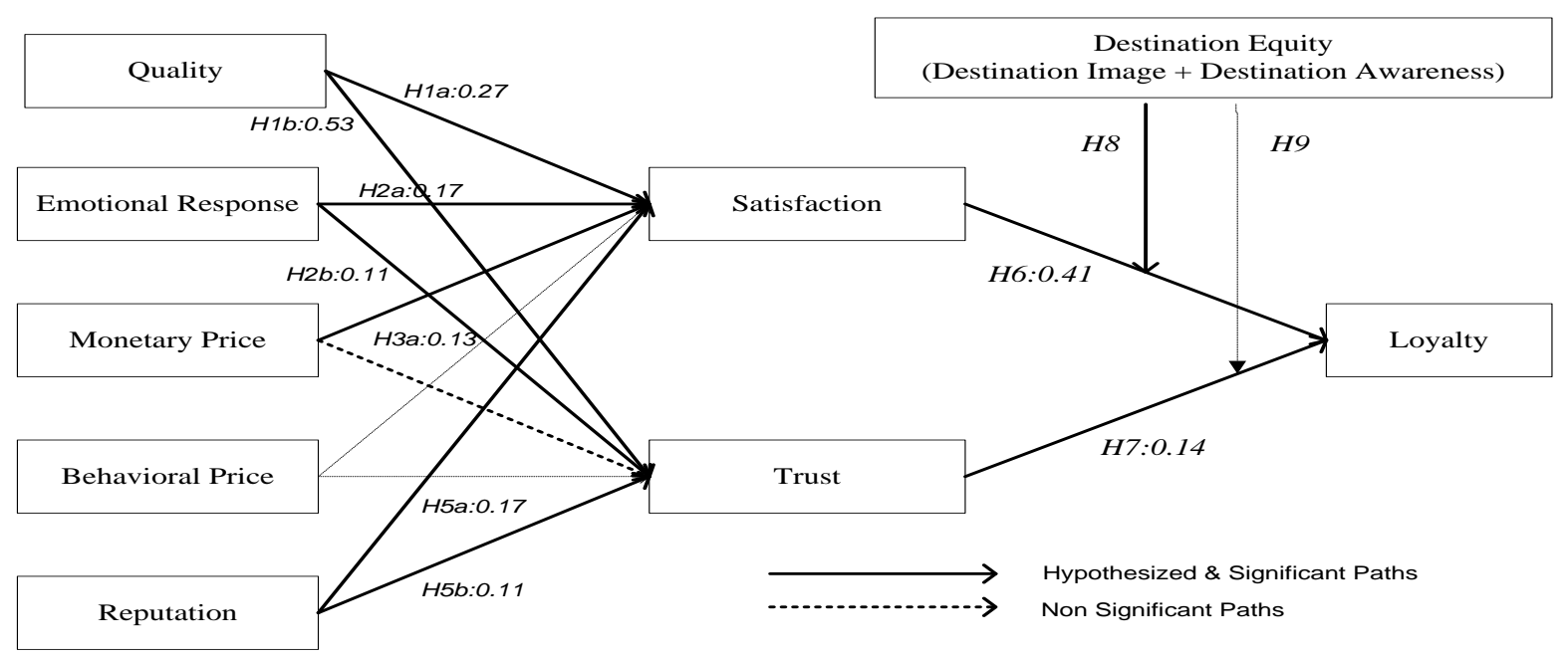

Figure 1: Conceptual Model

\section{Moderating Tests of Destination Equity}

The model specification required a test of the moderating influence of destination equity on the relationship between satisfaction, trust and loyalty constructs. To test the moderating effect, a multi-group path analysis was employed (Bagozzi and Yi, 1989). The multi-group path analysis is a technique especially appropriate when the covariance matrices differ significantly across treatments (Voss et al., 1998). It also enables a simultaneous estimation of all hypothesized relationships across groups. This approach also allows for restricted models with systematic constraints on posited relationships. These restricted models can be evaluated for their fit to data on the basis of a chi-square statistic, non-normed fit index (NNFI) or Tucker-Lewis index (TLI), comparative fit index (CFI), and other indicators, including the root mean square error of approximation (RMSEA) (Marsh et al., 1996).

Additional analysis was conducted to examine differences between the high and low destination equity groups. These differences were tested using a split-group analysis procedure (high versus low on the moderating variable) (Osterhus, 1997). The sample of 485 individuals was divided into two groups on the basis of the degree of 
destination equity by using high versus low median splits on the destination equity variables. The moderating effect of destination equity was tested and observed the relative change in model fit (Osterhus, 1997).

To assess the commonalities and differences between low and high destination equity groups, two alternative multiple sample models were estimated. First, a unconstrained model having no constraints across samples on the structural parameters was estimated. Then, a constrained model was estimated, in which the two relationships that were constrained to be equal across two samples. A significant interaction effect exists if the change in the chi-square value is significant. For the high versus low destination equity groups, the unconstrained model provided a Chi Square value of 838.98 (d.f. $=446, \mathrm{p}<0.000$ ). Note that the Chi Square value and degrees of freedom are equal to the respective sums for the structural models estimated separately for the two samples. The model with equality constrains on the two common relationships provided a chi square value of 850.09 (d.f. $=449, \mathrm{p}$ $<0.000)$. Of most interest here, though, was the rejection of the hypotheses that these two relationships were invariant across the two samples $\left(\Delta \chi^{2}{ }_{3}=11.11, \mathrm{p}<0.05\right)$. According to the Table of critical value of Chi-Square, critical value at the alpha of 0.05 (confidence level of $95 \%$ ) and degree of freedom of 3 is $7.82(11.11>7.82)$. Thus the difference is statistically significant at a less than 0.05 which suggests that destination equity has a moderating impact on the previously hypothesized relationships.

\section{Results of Moderation Tests}

The resulting unstandardized parameter estimates are presented in Table 4, revealing that the moderating effect of destination equity was apparent in the posited relationships between the mediating variable of satisfaction and the endogenous construct of loyalty at the significant level of 0.001 . Of the two proposed relationships testing moderating effects of destination equity, only one hypothesized relationship was statistically significant and in the hypothesized direction. When comparing across groups, unstandardized comparisons are recommended because indicators may have different variances, measurement error terms, and disturbance terms (Ping, 1995).

The findings indicate that the moderating effect of destination equity on the relationship between satisfaction and loyalty was significantly apparent in both groups but the magnitude of parameter estimates in the high destination equity group $(b=0.564, t=4.664)$ was greater than in the low group $(b=0.416, t=5.038)$. This finding provided support to $\mathrm{H}_{8}$. In contrast, no support for a moderating effect of destination equity on the influence of trust on loyalty was found, as evidenced by nonsignificant unstandardized parameter estimates for both the low (b $=0.044, \mathrm{t}=0.389)$ and high $(\mathrm{b}=0.080, \mathrm{t}=0.711)$ destination equity groups. Thus, $\mathrm{H}_{9}$ was not supported .

Table 4: Summary of Hypotheses Testing Results Showing Moderator Effects of Destination Equity

\begin{tabular}{|c|c|c|c|c|c|c|}
\hline & & & \multicolumn{2}{|c|}{$\begin{array}{c}\text { High } \\
\text { destination equity }\end{array}$} & \multicolumn{2}{|c|}{$\begin{array}{c}\text { Low } \\
\text { destination equity }\end{array}$} \\
\hline & & & Unstand Est. & t-value & Unstand Est. & t-value \\
\hline $\mathrm{H}_{8}$ & Satisfaction & Loyalty & 0.564 & 4.664 & 0.416 & 5.038 \\
\hline $\mathrm{H}_{9}$ & Trust & Loyalty & 0.080 & 0.711 & 0.044 & 0.389 \\
\hline \multicolumn{7}{|c|}{$\begin{array}{l}\text { Model Goodness-of-fit statistics: Chi-square }=838.98, \text { Degrees of freedom }=446, \chi^{2} / \mathrm{df}=1.88, \mathrm{p} \text { value }=0.000, \mathrm{GFI}= \\
0.844, \mathrm{AGFI}=0.791, \mathrm{RMSR}=0.106, \mathrm{TLI}=0.937, \mathrm{CFI}=0.949, \mathrm{NFI}=0.898 \text { and RMSEA }=0.049\end{array}$} \\
\hline
\end{tabular}

\section{DISCUSSION AND CONCLUSION}

It can be concluded that three out of five dimensions of perceived value have an effect on satisfaction and trust. Behavioral price has no effect at all on satisfaction and trust; while monetary price has effect solely on satisfaction. Considering the relative importance of each dimensions of perceived value, the quality dimension becomes the most important, followed by reputation, emotional value, and monetary price respectively. The result is consistent with empirical studies (Sanchez-Garcia et al., 2007) and makes intuitive sense. Since quality is what we want from the product/ service, the core service itself. The quality is consistent with functional value (Moliner et al., 2007). The reputation is consistent with social value, the way the service is perceived as having status or not. Emotional value is undeniable attribute since all spa customers not only seek treatment but also seek sense of happiness. 
Moreover, the findings support the effect of destination equity on the link from satisfaction to loyalty but not from trust to loyalty. When destination is perceived as having high equity, the more likely it is for the product sold by destination to be favored by customers. People's beliefs about a specific country affect their behavior in relation with products originating in this country (Parameswaran and Pisharodi, 1994).

\section{MANAGERIAL IMPLICATION}

The findings suggest that marketers of spa business can increase customer loyalty by providing four dimensions of value. First and most important dimension is quality which can be achieved by providing reliable and consistent quality. Secondly, marketer should build good reputation and status of spa business. Thirdly, marketer should focus on increasing emotional value by making spa experience a sense of joy and happiness. Finally, spa offering should be fairly priced and be a good bargain (Petrick, 2004). Apart from spa marketer, tourism marketer plays vital role in creating destination equity (awareness and image). Tourism marketer of Pattaya should project image of Pattaya as friendliness and hospitality. Furthermore, the governor of Pattaya should educate the critical role of being friendly and helpful host and encourage local people to have service mind toward tourists.

\section{LIMITATIONS}

Since the current study was limited to spa business during one time a year in one destination only, the current results can not be generalized. Although the theoretical model is supported by the literature review, it is necessary to strengthen the conclusions by applying them to other situations (Hernandez-Lobato et al., 2006). The study was further limited by not examining the impact of objective price on perceived value (Petrick, 2004). More research is necessary to determine other variables such as being first timers or repeaters, cultural differences and differences in socioeconomic background. Another limitation is that the current research only examined attitudinal loyalty in stead of behavioral loyalty or a composite one.

\section{ACKNOWLEDGEMENTS} research.

The authors wish to thank The Thailand Research Fund and Pattaya Municipality for sponsoring this

\section{AUTHOR INFORMATION}

Jirawat Anuwichanont is a full-time lecturer at Graduate School of Suan Dusit Rajabhat University, Thailand. He received his master and doctoral degree in Marketing from Thammasat University, Thailand. His research interests are in the areas of services marketing, more specifically on brand and customer loyalty in the airline context, sustainable tourism marketing and green marketing across cultures.

Panisa Mechinda is an assistant professor at Rajamagala University of Technology, Thanyaburi, Thailand. She received her doctorate in Marketing from Thammasat University, Thailand. Her research interests revolve around tourism marketing and service marketing, including consumer post purchase evaluations (loyalty, switching barriers, customer satisfaction): as well as the internal drivers of frontline employees' customer oriented behavior.

\section{REFERENCES}

1. $\quad$ Aaker, D.A. 1991, Managing brand equity. The Free Press: New York.

2. $\quad$ Aaker, D.A. 1996, Building strong brand. The Free Press: New York.

3. Anselmsson, J., Johnansson, U., \& Persson, N. 2007, 'Understanding price premium for grocery products: a conceptual model of customer-based brand equity', Production \& Brand Management, vol. 16, no.6, pp. 401-414.

4. Assael, H. 1995, Consumer behaviour and marketing action. South Western College: Cincinnati.

5. Backman, S.J., \& Crompton, J.L. 1991, 'The usefulness of selected variables for predicting activity loyalty', Journal of Leisure Science, vol. 13, pp. 205-220. 
6. Bagozzi, R.P., \& Yi, Y. 1988, 'On the use of structural equation models in experimental designs', Journal of Marketing Research, vol. 26, August, pp. 271-284.

7. Baloglu, S., \& McCleary, K. 1999, 'I shape for the formation of the image of a destiny', Journal of Tourism Research in Spanish, vol. 1, no. 2, pp. 325-355.

8. Barclay, D.W. \& Smith, J.B. 1997, 'The effects of organizational differences and trust on the effectiveness of selling partner relationships', Journal of Marketing, vol.61, no. 1, pp. 3-21

9. Barsky, J.D. 1992, 'Customer satisfaction in the hotel industry: Meaning and measurement', Hospitality Research Journal, vol. 16, no. 1, pp.51-73

10. Beckett B., Hewer, P., \& Howcroft, B. 2000, 'An exposition of consumer behavior in the financial service industry', International Journal of Bank Marketing, vol. 18, no. 1, pp. 15-26.

11. Bei, L. T. and Y. C. Chiao, 2001, 'An integrated model for the effects of perceived product, perceived service quality, and perceived price fairness on consumer satisfaction and loyalty', Journal of Consumer Satisfaction, Dissatisfaction and Complaining Behavior, vol.14, pp. 125-140.

12. Bejou, D., \& Palmer, A. 1998, 'Trust ethics and relationship satisfaction', International Journal of Bank Marketing, vol. 16, no. 4, pp. 170-175.

13. Berthon, P., Hulbert, J.M., \& Pitt, L.F. 1999, 'Brand management prognostications', Sloa Management Review, vol. 40, no. 2, pp. 53-65.

14. Bitner, M. J., Booms, B. H. \&Tetreault, M. S. 1990, 'The service encounter: diagnosing favorable and unfavorable incidents', Journal of Marketing, vol. 54, pp. 71-84.

15. Bloemer, J., \& Odekerken-Schroder, G. 2002, 'Store satisfaction and store explained by customer and store related factors', Journal of Customer Satisfaction, Dissatisfaction and Complaining Behavior, vol. 15, pp. 68-80.

16. Bollen, K.A. 1989, Structural equations with latent variables. New York: Wiley.

17. Bolton, R.N., \& Drew, J.H. 1991, 'A multistage model of customers' assessments of service quality and value', Journal of Consumer Research, vol. 17, March, pp. 275-284.

18. Crompton, J.L. 1979, 'An assessment of the image of Mexico as a vacation destination and the influence of geographical location upon that image', Journal of Travel Research, vol. 14, no. 4, pp. 18-23.

19. Crosby, L., Kenneth, E., \& Deborah, C. 1990, 'Relationship quality in services selling: an interpersonal influence perspective', Journal of Marketing, July.

20. Cunningham, R.M. 1956, 'Brand loyalty: what, where, how much?', Journal of Marketing, vol. 2, p. 206.

21. Day, G.S. 1969, 'A two-dimensional concept of brand loyalty', Journal of Advertising Research, vol. 9,

22. Delgado-Ballester, E., \& Munuera-Aleman, J.L. 2000, 'Diners' perceptions of quality, value and satisfaction', Cornel; Hotel and Restaurant Administration Quarterly, vol. 41, no. 3, pp. 58-82

23. Delgado-Ballester, E., \& Munuera-Aleman, J.L. 2001, 'Brand trust in the context of consumer loyalty', European Journal of Marketing, vol. 35, no. 11/12, pp. 1238-1258.

24. Dick, A., \& Basu, K. 1994, 'Customer loyalty: toward an integrated conceptual framework', Journal of the Academy of Marketing Science, vol. 22, no. 2, pp. 99-113.

25. Dodds, W.B., Monroe, K.B., \& Grewal, D. 1991, 'The effect of price, brand and store information on buyers' product evaluations', Journal of Marketing Research, vol. 18, pp. 39-50.

26. Doney, P.M., \& Cannon, J.P. 1997, 'An examination of the nature of trust in buyer-seller relationships', Journal of Marketing. vol. 61, April, pp. 35-51.

27. Echter, M., \& Ritchie, J.R. 2003, 'The meaning and measurement of destination image', Journal of Tourism Studies, vol. 14, no. 1, May.

28. Ehrenberg, A.S.C., \& Goodhard, G.J. 1989, 'Understanding buyer behavior', In Consumer Psychology in Behavioral Perspective, Fox, G. et al., (Ed.) Rutledge: London, pp.15.

29. Ennew, G., Watkins, T., \& Wright, M. 1995, Marketing financial service, butterworth-heinemann. UK: Oxford

30. Farquhar, P.H. 1989, 'Managing brand equity', Journal of Marketing Research, vol. 1, pp. 24-33.

31. Fesenmaier, D., Vogt, C.A., \& Stewart, W.P. 1993, 'Investigating the influence of welcome center information on travel behavior', Journal of Travel Research, vol. 31, Winter, pp. 47-51.

32. Fornell, C. 1992, 'A national customer satisfaction barometer: the Swedish experience', Journal of Marketing, vol. 56, no. 1, pp. 6-21.

33. Fornell, C., \& Larcker, D.F. 1981, 'Evaluating structural equation models with unobservable variables and measurement error', Journal of Marketing Research, vol. 18, pp. 39-50. 
34. Frank, R.E. 1962, 'Brand choice as a probability process', Journal of Business, vol. 35, no. 1, pp. 43-56.

35. Gale, B.T. 1994, 'Managing customer value: Creating quality and service that customers can see', New York: The Free Press.

36. Ganesan, S. \&R. L. Hess (1997), "Dimensions and Levels of Trust: Implications for Commitment to a relationship," Marketing Letters, vol. 8, no. 4, pp. 439-448.

37. Ganesan, S. 1994, 'Determinants of long-term orientation in buyer-seller relationships', Journal of Marketing, vol. 58, pp. 1-19.

38. Garbarino, E., \& Johnson, M.K. 1999, 'The different roles of satisfaction, trust and commitment in customer relationships, Journal of Marketing, vol. 63, April, pp. 70-87.

39. Gibson, J., Qi, H.X., \& Zhang, J.J. 2008, 'Destination image and intent to visit China and the 2008 Beijing Olympic games', Journal of Sport Management, vol. 22, pp. 427-450, Florida.

40. Green, D.H., Barclay, D.W., \& Ryans, A.B. 1995, 'Entry strategy and long-term performance: conceptualization and empirical examination', Journal of Marketing, vol. 59, October, pp. 1-16.

41. Hair, J.F., Anderson, R.E., Tatham, R.L., \& Black, W.C. 1995, Multivariate data analysis with readings. $4^{\text {th }}$ ed., Upper Saddle River, NJ: Prentice-Hall.

42. Hair, J.F., Anderson, R.E., Tatham, R.L., \& Black, W.C. 1998, Multivariate data analysis. $5^{\text {th }}$ ed, Upper Saddle River, NJ: Prentice-Hall.

43. Harrison T. 2000, 'Financial services marketing, Pearson education: Harlow, England', in 'Place bonding for recreation places: conceptual and empirical development', Hammitt, W.E., Backlund, E.A., \& Bixler, R.D. (Eds.) 2006, Leisure Studies, vol. 25, no. 1, pp. 17-41.

44. Hart, C.W., Heskett, J.L., \& Sasser, W.E. 1990, 'The profitable art of service recovery'. Harvard Business Review, vol. 68, pp. 148-156.

45. Hennig-Thurau, T., Gwinner, K., \& Gremler, D. 2002, 'Understanding relationship marketing outcomes'. Journal of Service Research, vol. 4, no. 3, pp. 230-247.

46. Hepworth, M., \& Mateus, P. 1994, 'Connecting customer loyalty to the bottom line', Journal of Canadian Business Review, vol. 21, no. 4, pp. 40-44.

47. Hernandez-Lobato, L., Solis-Radilla, M. M., Moliner-Tena, M.A., \& Sanchez-Garcia, J. 2006, 'Tourism destination image, satisfaction and loyalty: a study in Ixtapa-Zihuatanejo, Mexico', Tourism Geographies, vol. 8, no. 4, pp. 343-358.

48. Hess. J.S. 1995, 'Construction and assessment of a scale to measure consumer trust', in Enhancing knowledge development in marketing. Barbara B.S., \& George, M.Z. (Eds) Chicago: American Marketing Association. pp. 20-26.

49. Hosany, S., Ekinci, Y., \& Uysal, M. 2006 'Destination image and destination personality: an application of branding theories to tourism places', Journal of Business Research, vol. 59, pp. 638-642.

50. Hunt, J.D. 1975, 'Image as a factor in tourism development', Journal of Travel Research, vol. 13, no.3, pp. $1-7$.

51. Jacoby, J., \& Chestnut, R.W. 1978, Brand loyalty: measurement and management. New York: John Wiley.

52. Jacoby, J., \& Olson, J. C. 1977, 'Consumer response to price: an attitudinal, information processing perspective, in Y.Wind and P. Greenberg (Eds.), Moving Ahead with Attitude Research, 73-86. Chicago: American Marketing Association.

53. Jago, L.K., \& Shaw, R.N. 1998, 'Special events: a conceptual and definitional framework', Festival Management and Event Tourism, vol. 5, no. 1, pp. 21-32.

54. Johnson, M.D. (1998), Customer Orientation and Market Action, Upper Saddle River, NJ: Prentice Hall

55. Jones, T.O., \& Sasser, E.W. 1995, 'Why satisfied customers defect', Journal of Harvard Business Review, November/December, pp. 88-99.

56. Kaplanidou-Kyriaki, \& Vogt-Christine 2007, 'The interrelationship between sport event and destination image and sport tourists' behaviors', Journal of Sport, Tourism, vol. 12, no, 3-4, pp. 183-206.

57. Keller, K.L. 1993, 'Conceptualizing, measuring, and managing customer-based brand equity', Journal of Marketing, vol. 57, pp. 1-22.

58. Knight, G.A., \& Calantone, R.J, 2000', A flexible model of consumer country-of origin perceptions. Journal of International Marketing Review, vol. 17, no. 2, pp. 127-145.

59. Konecnik-Maja 2006 'Croatian-based brand equity for Slovenia as a tourism destination', Journal of Economic and Business Review for Central and South-Eastern Europe, vol. 8, no. 1, February. 
60. Kozak, M., \& Rimmington, M. 2000, 'Tourist satisfaction with Mallorca, Spain as an off-season holiday destination', Journal of Travel Research, vol. 38, February, pp. 260-269.

61. Kramer, R. M. 1999, 'Trust and distrust in organizations: Emerging perspectives, enduring questions', Annual Review of Psychology, vol. 50, pp. 569-598.

62. Kumar, N., Scheer, L.K., \& Steenkamp, J.E.M. 1995, 'The effects of perceived interdependence on dealer Attitudes', Journal of Marketing Research, vol. 32, pp. 348-356.

63. Laroche, M., Papadopoulos, N., Heslop, L.A., \& Mourali, M. 2005, 'The influence of country image structure evaluations of foreign products', Journal of International Marketing Review, vol. 22, no. 1, pp. 96-115.

64. Lassar, W., Mittal, B., \& Sharma, A. 1995, 'Measuring customer-based brand equity', Journal of Consumer Marketing, vol. 12, no. 4, pp. 11-19.

65. Latour, \& Peat 1979, 'Conceptual and methodological issues in consumer satisfaction research', in Advances in Consumer Research, Wilkei, W.L. (Ed.), vol. 8.

66. Lee, J., Lee, J., \& Feick, L. 2001, 'The impact of switching cost on the customer satisfaction-loyalty link: mobile phone service in France', Journal of Services Marketing, vol. 15, pp. 35-48.

67. Lewis, R., \& Soureli, M. 2006 'The antecedents of consumer loyalty in retail banking', Journal of consumer Behaviour, vol. 5, pp. 15-31.

68. Lim, K., \& O’Cass, A. 2001, 'Consumer brand classifications: an assessment of culture-of-origin versus country-of-origin', Journal of Production Brand Management, vol. 10, no. 2, pp. 120-136.

69. Marsh, H., Balla, J., \& Hau, K. 1996, 'A valuation of incremental fit Indices: a clarification of mathematical and Empirical properties'. in Advanced Structural Modeling: Issues and Techniques.

Marcoulides, G, \& Schumacker, R. (Eds.) Mahwah, NJ: Lawrence Associates, pp. 315-345.

70. Milman, A., \& Pizam, A. 1995, 'The role of awareness and familiarity with a destination: the central Florida case', Journal of Travel Research, vol. 33, no. 3, pp. 21-27.

71. Moliner, M.A., Sanchez, J., Rodriquez, R. M., \& Callarisa, L. 2006, 'Relationship quality with a travel agency: the influence of the postpurchase perceived value of a tourism package', Tourism and Hospitality Research, vol. 7, no. 3/4, pp. 194-211.

72. Montesions, M., Roth, R., \& Diamantopoulos, B. 2006, 'Country image, country brand equity product preferences: a test of two models', The $35^{\text {th }}$ EMAC Conference-University of Athens, vol. 22-23, May.

73. Moorman, C, R., Deshpande, \& Zaltman, G. 1993, 'Factors affecting trust in market research relationships', Journal of Marketing, vol. 57, pp. 81-101.

74. Morgan, R.M., \& Hunt, S.D. 1994, 'The commitment-trust theory of relationship marketing', Journal of Marketing, vol. 58, July, pp. 20-38.

75. Nunnally, J.C. 1978, Psychometric theory. New York: McGraw-Hill.

76. O’Brien, L., \& Jones, C. 1995, 'Do rewards really create loyalty', Journal of Hardware Business Review, vol. 73, pp. 75-82.

77. Oliver, R.L. 1980, 'A cognitive model of the antecedents and consequences of satisfaction decisions', Journal of Marketing Research, vol. 17, November, pp. 460-469.

78. Oliver, R.L. 1992, 'An investigation of the attribute basis of emotion and related affects in consumption: suggestions for a stage-specific satisfaction framework', in Advance in Consumer Research, vol. 19, Sherry, J., \& Sternthal, B. (Eds.) Provo, UT: Association for Consumer Research, Fourthcoming.

79. Oliver, R.L. 1999, 'Whence consumer loyalty?', Journal of Marketing, vol. 63, pp. 33-44.

80. Oliver, R.L., \& Swan, J.E. 1989, 'Consumer perceptions of interpersonal equity and satisfaction', Journal of Marketing, vol. 53, pp. 21-35.

81. Oliver, R.L. \& Desarbo, W.S. 1988, 'Response determinants in satisfaction judgments', Journal of Consumer Research, vol. 14 (March), pp. 495-507.

82. Oliver, R. L. 1981, 'Measurement and evaluation of satisfaction processes in retail settings', Journal of Retailing, vol. 57 (Fall), pp. 25-48.

83. Olsen, S.O. 2002, 'Comparative evaluation and the relationship between quality, satisfaction, and repurchase Loyalty', Journal of the Academy of Marketing Science, vol. 30, no, 3 pp. 240-249

84. Oppermann, M. 1999, 'Whence consumer loyalty', Journal of Marketing, vol. 63, Special issue, pp. 33-44.

85. Oppermann, M. 2000, 'Tourism destination loyalty’, Journal of Travel Research, vol. 39, no. 1, pp. 78-84.

86. Parameswaran, R.\& Pisharodi, R.M. 1994, 'Facets of country of origin image: an empirical assessment', Journal of Advertising, vol. 13 no.1, pp.43-56. 
87. Parameswaran, R., \& Pisharodi, R.M. 2002, 'Assimilation effects in country image research', Journal of International Marketing Review, vol. 19, no. 2, pp. 259-279.

88. Parasuraman, A. 1997, 'Reflections on gaining competitive advantage through customer value', Journal of the Academy of Marketing Science, vol. 25, no. 2, pp. 154-164.

89. Parasuraman, A., \& Grewal, D. 2000, 'The impact of technology on the quality-value-loyalty chain: a research agenda', Journal of the Academy of Marketing Science, vol. 28, no. 1, pp. 168-174.

90. Patterson, P., \& Spreng, R. 1997, 'Modeling the relationship between perceived value, satisfaction and repurchase intention in a business-to-business, service context: an empirical examinational', International Journal of Service Industry Management, vol. 8, no. 5, pp. 414-434.

91. Patterson, P.G., Johnson, L.W., \& Spreng, R. 1997, 'Modeling the determinants of customer satisfaction for business-to-business professional services', Journal of Academy of marketing Science, Winter, pp. 4-17.

92. Pearce, P.L. 1982, 'Perceived changes in holiday destinations', Annals of Tourism Research, vol 9, pp. 145164.

93. Perin, M.G., Sampaio, C.H., \& Brei V.A. 2006, 'Loyalty’s antecedents: a cross-sector study', Latin American Business Review, vol.8, no.1, pp. 83-102.

94. Petrick, F. 2004, 'First timers 'and repeaters' perceived value', Journal of Travel Research, vol. 43, August, pp. 29-38.

95. Petrick, J. F. 2002, 'Development of a multi-dimensional scale for measuring the perceived value of service', Journal of Leisure Research, vol.34, no. 2, pp. 119-134.

96. Petrick, J. F and Backman, S. J. 2002, 'An examination of the determinants of golf travelers' satisfaction', Journal of Travel Research, vol. 40, pp. 252-258

97. Petrick, J.F., \& Backman, S.J. 2001, 'An examination of golf travelers' satisfaction, perceived value, loyalty, and intentions to revisit', Journal of Tourism Analysis, vol. 6, no. 3/4, pp. 223-237.

98. Ping, R.A. 1995, 'A parsimonious estimating technique for interaction and quadratic latent variables', Journal of Marketing Research, vol. 32, pp. 336-347

99. Pritchard, M., Havitz, M., \& Howard, D. 1999, 'Analyzing the commitment loyalty link in service contexts', Journal of Academy of Marketing Science, vol. 27, no. 3, pp. 333-348.

100. Raggio, R.D. \& Leone, R. P. 2007, 'The theoretical separation of brand equity and brand value: Managerial implications for strategic planning', Journal of Brand Management, vol. 14, no. 5 pp. 380-395.

101. Reicheld, F., \& Sasser, W. 1990, 'Zero defections: quality comes into services', Journal of Harvard Business Review, September-October, pp. 105-111.

102. Reichheld, F., \& Schefter, P. 2000, 'E-loyalty: your secret weapon on the web', Harvard Business Review, vol. 78, July/August, pp. 105-113.

103. Reid, L.J., \& Reid, S.D. 1993, 'Communicating tourism suppliers: service building repeat visitor relationships', Journal of Travels and Tourism Marketing, vol. 2, no. 2/3, pp. 3-20.

104. Rossiter, J.R., \& Percy, L. 1987, Advertising and promotion management. New York: McGraw-Hill.

105. Rust, R.T. \& Oliver, R.L. 1994, 'Service quality: new directions in theory and practice', Thousand Oaks, Calif.: Sage Publications

106. Sanchez-Garcia, Miguel A., Moliner-Tena, Callarisa-Fiol, \& Rodriguez-Artola, M. 2007, 'Relationship quality of an establishment and perceived value of a purchase', The Service Industries Journal, vol. 27, no. 2, March, pp. 151-174.

107. Sake, 1. M. 1992. Prices, quality and trust: inter-firm relations in Britain and Japan (Cambridge University Press, Cambridge.

108. Se-Hyuk, P. 1996, 'Relationships between involvement and attitudinal loyalty constructs in adult fitness programs', Journal of Leisure Research, vol. 28.

109. Simon, C.J., \& Sullivan, M.W. 1992, 'A financial approach to estimating firm-level brand equity and measuring the impact of marketing events', Report Number 92-116, Cambridge, MA: Marketing Science Institute.

110. Singh, J., \& Sirdeshmukh, D. 2000, 'Agency and trust mechanisms in consumer satisfaction and loyalty judgments', Journal of the Academy of Marketing Science, vol. 28 no. 1, pp. 150-167.

111. Sirdeshmukh D., Jagdip, S., \& Barry, S. 2002, 'Consumer trust, value, and loyalty in relational exchanges', Journal of Marketing, vol. 66, pp. 15-37.

112. Sweeney, J.C. \& Soutar, G. N. 2001, 'Consumer perceived value: the development of a multiple item scale', Journal of Retailing, vol. 77, pp. 203-220. 
113. Sweeney, J.C., Soutar, G. N., \& Johnson, L.W. 1998, 'Consumer perceived value: Development of a multiple item scale', American Marketing Association Conference Proceedings, vol. 9, no. 138.

114. Tabachnick, B.G., \& Fidell, L.S. 2001, Using multivariate statistics. $4^{\text {th }}$ ed, New York: Harper-Collins.

115. Tourism Authority of Thailand, viewed 20 June 2005, <http://www.tat.or.th〉 vol. 78, July/August, pp. 105-113.

116. Tse, D.K. \& Wilton, P.C. 1988, 'Models of consumer satisfaction formation: an extension', Journal of Marketing Research, No.17, pp.460-69.

117. Voss, G.B., Parasuraman, A., \& Grewal, D. 1998, 'The roles of price, performance, and expectations in determining satisfaction in service exchanges', Journal of Marketing, vol. 62, October, pp. 441-476.

118. Wang 2002, 'Attitudinal correlates of brand commitment: an empirical study', Journal of Relationship Marketing, vol. 1, no. 2.

119. Woodruff, R.B. 1997, 'Customer value: the next source for competitive advantage', Journal of the Academy of Marketing Science, vol. 25, no. 2, Spring, pp. 139-153.

120. Woodruff, R.B., \& Gardial, S.F. 1996, 'Know your customer: New approaches to understanding customer value and satisfaction', Cambridge, MA:Blackwell Publishers.

121. Woodside, A.G., \& Lysonski, S. 1989, 'A general model of traveler destination choice', Journal of Travel Research, vol. 27, no. 4, pp. 8-14.

122. Yang, Z., \& Peterson, R.T. 2004, 'Customer perceived value, satisfaction, and loyalty: The role of switching costs', vol. 21, no. 10, October, pp. 799-822.

123. Yoo, B, Donthu, N., \& Lee, S. 2000, 'An examination of selected marketing mix element and brand equity', Journal of the Academy of Marketing Science, vol. 18, no. 2, pp. 195-211.

124. Zeithaml, V.A. 1988, 'Consumer perceptions of price, quality and value: a means-end model and synthesis of evidence', Journal of Marketing, vol. 52, July, pp. 2-22.

125. Zeithmal, V.A., Berry, L.L., \& Parasuraman A. 1996, 'Problems and strategies in services marketing', Journal of Marketing, vol. 60, April, pp. 31-46. 
NOTES 